\title{
Development and Exploring the Effectiveness of an Educational Package for Coping with the Occupational Stress of a Flight Crew
}

\author{
Shiva Sakhaie ${ }^{1}$, Mohamad Asgari*2 ${ }^{(D)}$, Ahmad Borjali³ ${ }^{3}$ Amirhosein Mahmodi ${ }^{4}$
}

1. Department of Educational Science and Counselling, College of Psychology and Educational Sciences, Central Tehran Branch, Islamic Azad University, Tehran, Iran

2. Department of Psychometrics, College of Psychology and Educational Sciences, Allameh Tabatabai University, Tehran, Iran

3. Department of Psychology, College of Psychology and Educational Sciences, Allameh Tabatabai University Tehran, Iran

4. Department of Educational Management, Faculty of Psychology and Social Sciences, Central Tehran Branch, Islamic Azad University, Tehran, Iran

Article Info
Received: 2020/04/25;
Accepted: 2020/06/27;
ePublished: 2020/07/03
doi 10.30699/jergon.8.1.56
Use your device to scan
and read the article online
Q
Corresponding Author
Mohamad Asgari
Department of Psychometrics,
College of Psychology and
Educational Sciences, Allameh
Tabatabai University, Tehran,
Iran
Email: drmasgari@ atu.ac.ir

\begin{abstract}
Background and Objectives: Job stress is among the factors that affect job performance. The present study aimed at the developing and studying the effectiveness of an educational package to cope with the occupational stress of the flight crew.
\end{abstract}

Methods: The research method is mixed (qualitative \& quantitative). The statistical population in the qualitative section consists of elites and informants in the field of coping strategies for the flight crew's stress and seven people were selected by targeted sampling method. In the quantitative method, the statistical population included Mahan flight crew and forty people were selected through convenient sampling and they were randomly assigned into two experimental and control groups. The quasi-experimental method with an unbalanced control group was used. The Vandroff's Job Stress Questionnaire was used for measuring the dependent variable. The data were analyzed by Multivariable Variance method and Independent t-test for differential scoring using SPSS 25 software.

Results: The results indicated that the educational package of coping with occupational stress led to the reduction of stress in the flight crew. The analysis of each occupational stress components showed that the training for coping with the occupational stress is effective for, Decision-making Power, job \& time strain, role ambiguity, value deficiency, as well as social support from the manager and colleagues.

Conclusion: Thus, according to the effectiveness of the educational package for coping with occupational stress, it is recommended that this package be used in other airline companies and also by the psychologists and consultants who utilize occupational therapy for the occupational stress of the flight crew.

Keywords: Educational package of occupational stress, Time \& work pressure, Decision-making power, Flight crew

Copyright ( 0 2020, This is an original open-access article distributed under the terms of the Creative Commons Attribution-noncommercial 4.0 International License which permits copy and redistribute of the material just in noncommercial usages with proper citation.

How to Cite This Article:

Sakhaie S, Asgari M, Borjali A, Mahmoodi A. Development and Exploring the Effectiveness of an Educational Package for Coping with the Occupational Stress of a Flight Crew. Iran J Ergon. 2020; 8 (1):56-65 
تدوين و مطالعةٌ اثربخشى بستةُ آموزشى مقابله با استرس شغلى كادر :يرواز

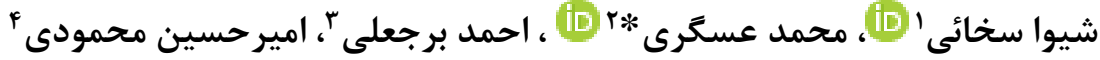

' . ₹روه تربيتى و مشاوره، دانشكده علوم تربيتى و روانشناسى، دانشعاه آزاد اسلامى واحد تهران مركزى، تهران، ايران

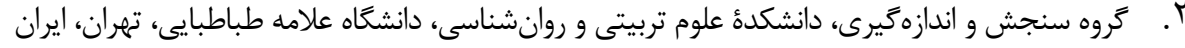

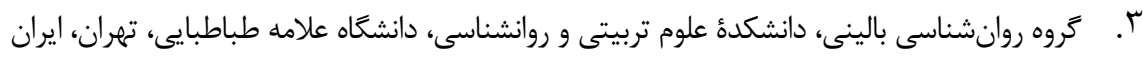

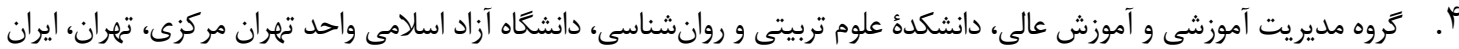

\begin{tabular}{|c|c|}
\hline خلاصه & اطلاعات مقاله \\
\hline 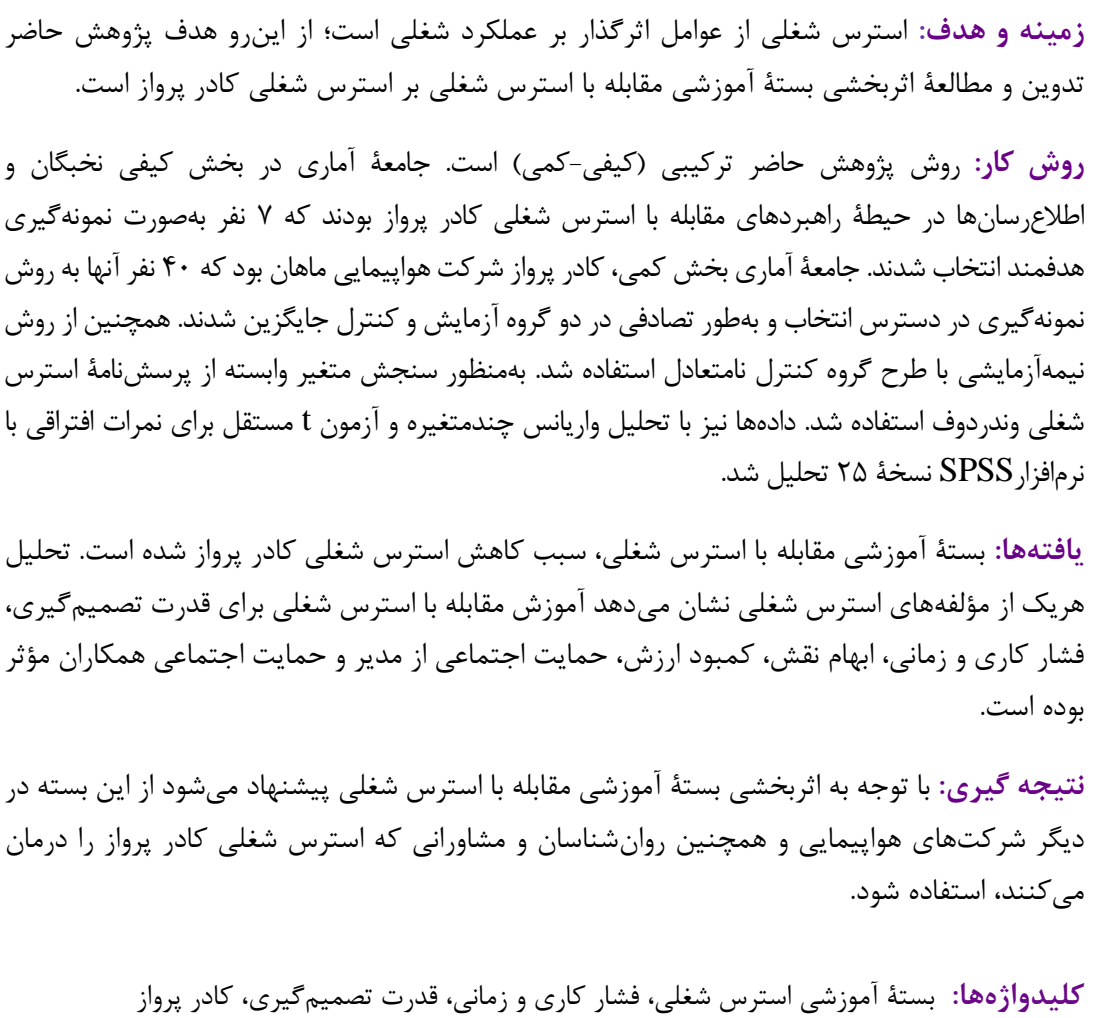 & 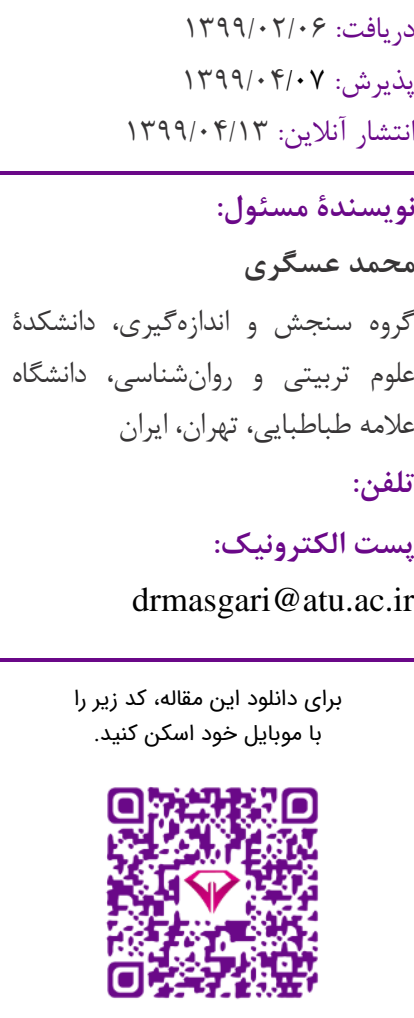 \\
\hline
\end{tabular}

مقدمه

اما ممكن است در معرض تنش و عوامل استرسزاى شغلى قرار بخيرد و درنتيجه نيروى كارآمدى نداشته باشد. همجنين

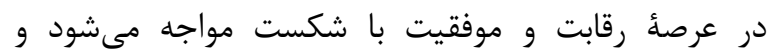

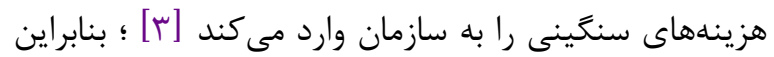
امروزه ييشخيرى و تأمين سلامت روانشناختى كاركنان سنان واز اولويتها و موضوعات مطرح در حيطة فعاليت سازمانها

$$
\text { محسوب مىشود. }
$$

روشهاى مقابله با استرس در برخى محيطها به توجه بيشترى نيازمند است. از جملأ اين محيطها مىتوان به كادر
سازمانها علاوه بر دارايىهاى مادى، دارايى ديخرى به نام

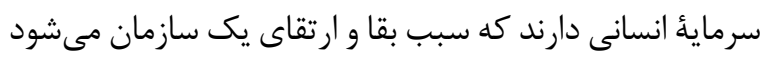
[ [1]. Fاهى در محيط شغلى، عامل انسانى در معرض تنش هاى عصبى و روانى گَوناگونى قرار مى گيرد. يكى از اين عوامل تنشزا، استرس شغلى است. اين تنش زمانى به وجود مىآيد كه خواستههاى محيط كار و فشارهاى مرتبط با آن، با بان ويزگ هى هاى فرد همخوانى ندارد و درنتيجه از توانايى فرد خارج

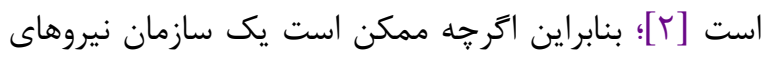

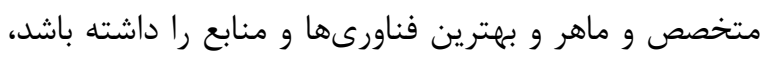


شيوا سخائى و همكاران | تدوين و مطالعئ اثربخشى بستئ آموزشى مقابله با استرس شغلى كادر برواز

عملكرد شغلى در كار كنان مراقبت يرواز است. همجزنين آنها

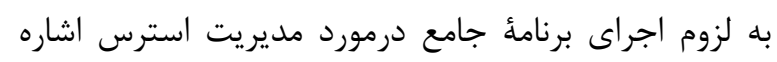

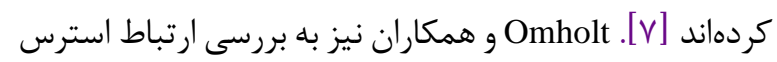

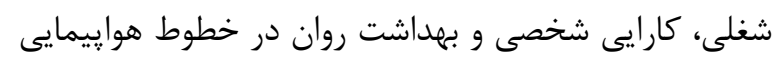

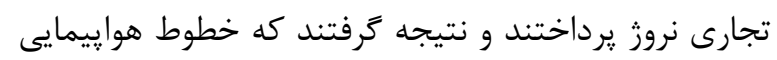

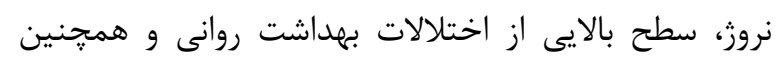
سطوح بالاى استرس شغلى مرتبط با بسيارى از ازتئلات اختلالات

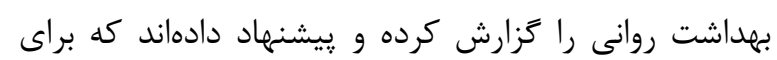

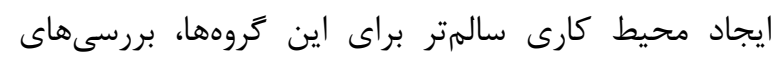

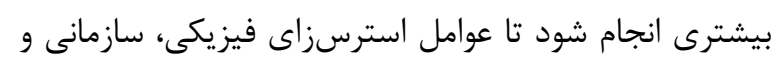

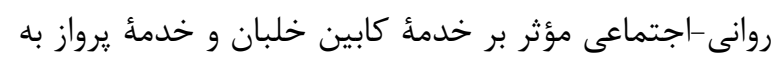
دست بيايد [م]. در يزوهشى ديكر، استرس خلبانان شامل استرس زندى دئ،

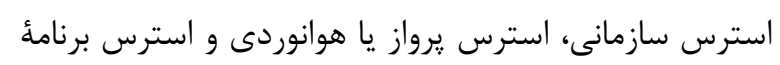

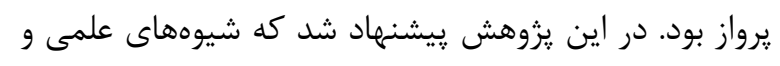

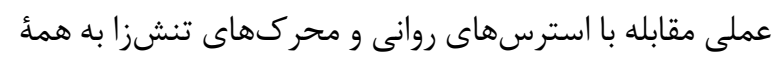

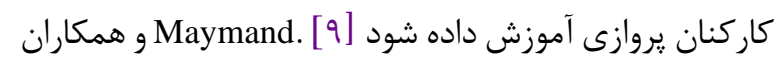

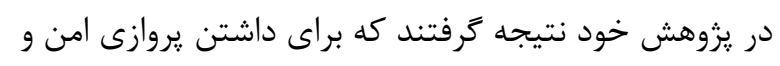

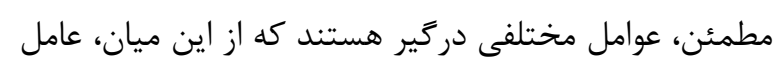

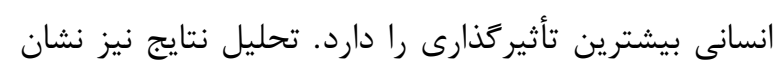

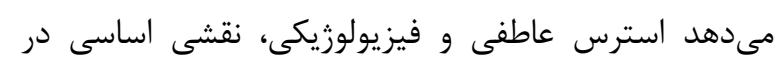

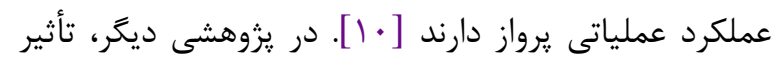

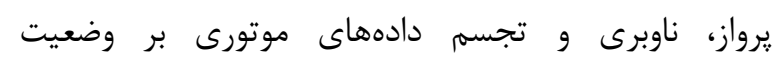

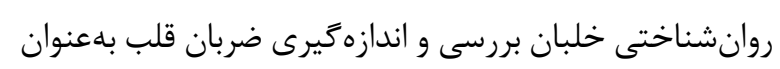

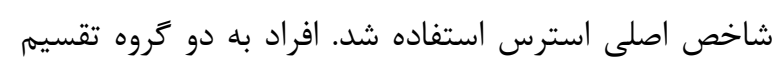

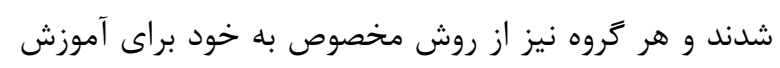

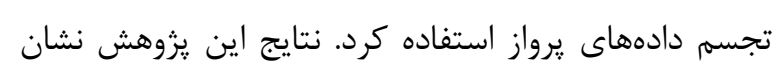

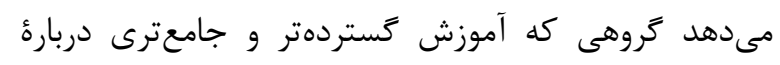

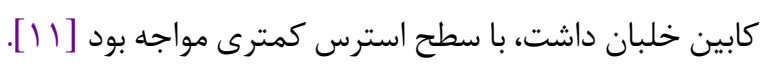

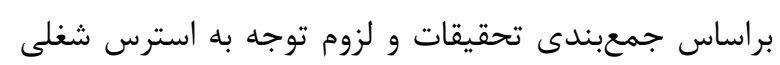

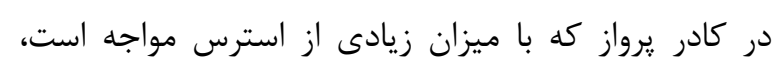

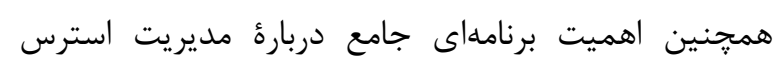

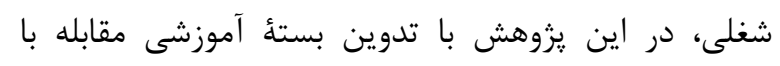

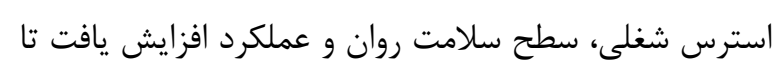

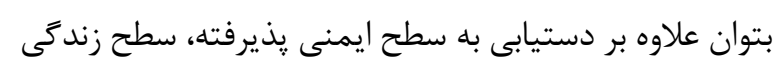

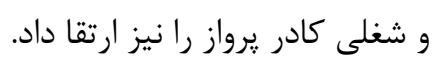

روش كار

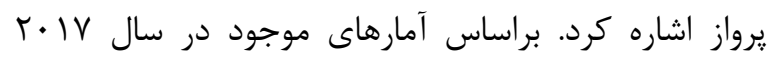
سومين شغل براسترس دنيا، به اعضاى كادر برواز مربوط است است. يكى از دلايل وقوع سوانح و حوادث هوايى، انسان و خطاهاى براى بران

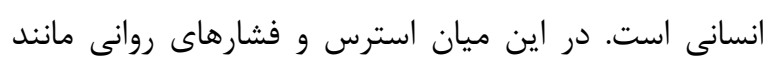

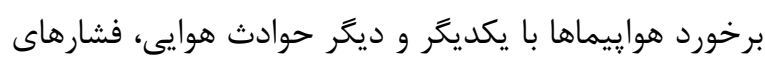

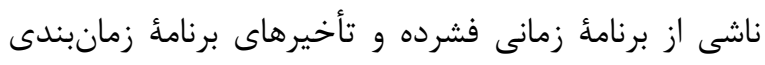

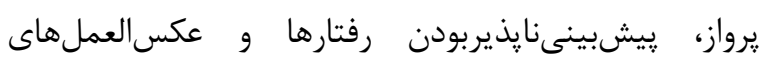

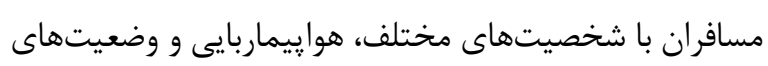

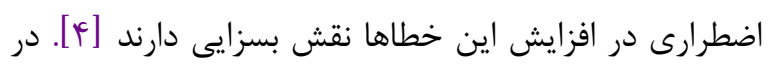

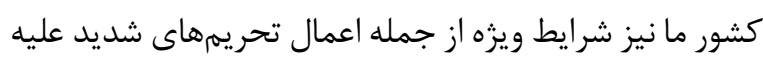

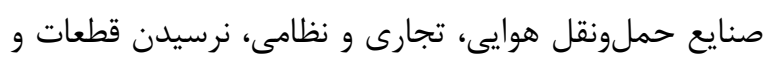

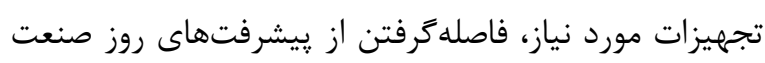

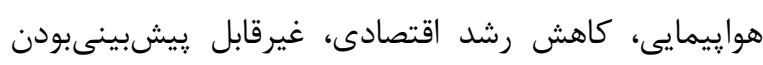

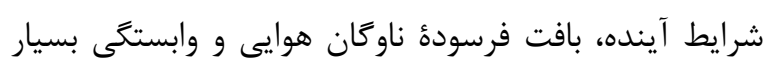

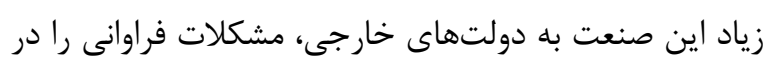

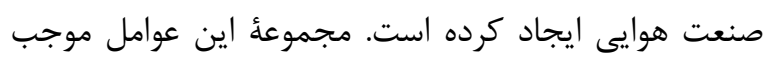

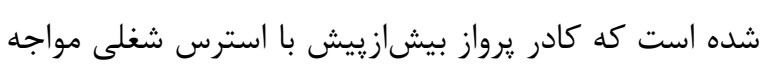

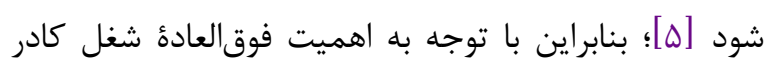

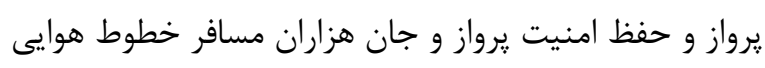

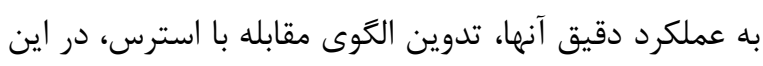

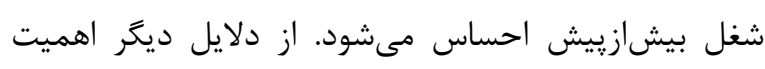

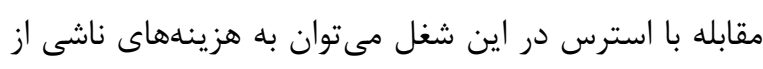

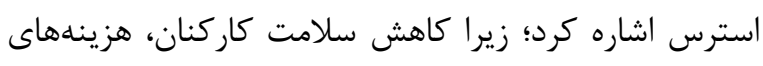

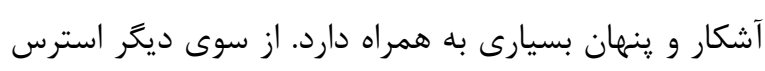

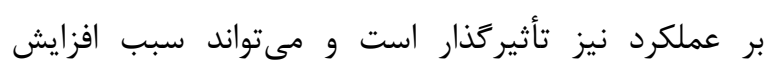

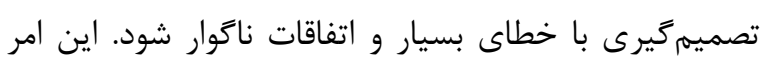

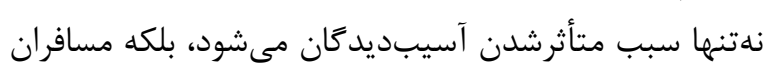

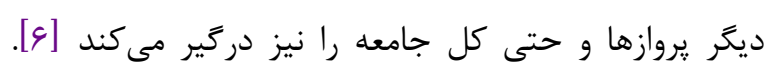

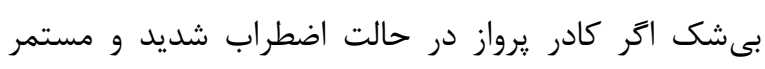

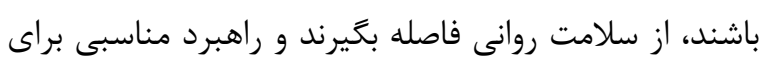

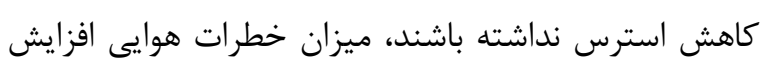

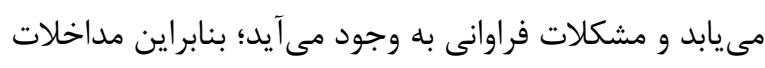

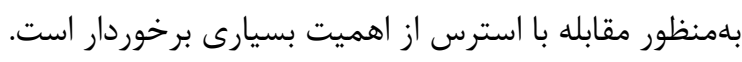

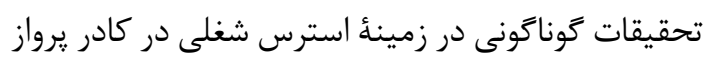

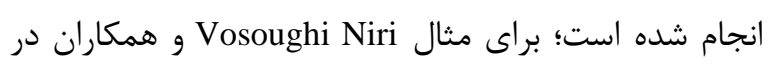

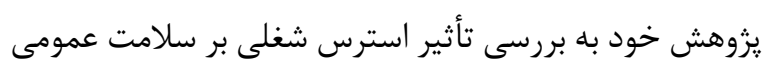

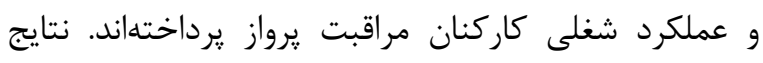

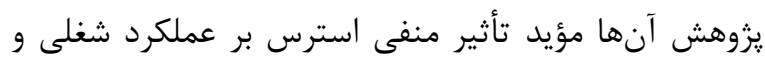
همجنين نقش واسطهاى سلامت عمومى درباره استرس و و 


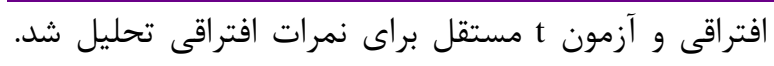

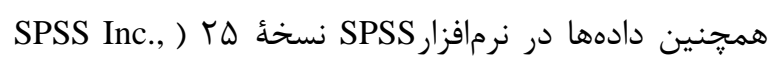
(Chicago, Ill., USA

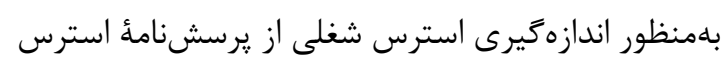

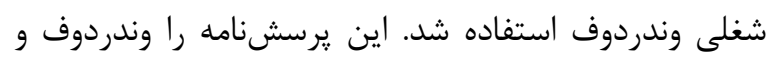

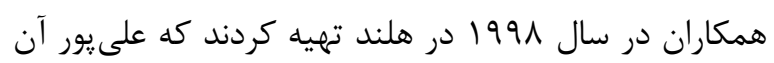

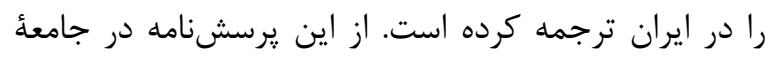

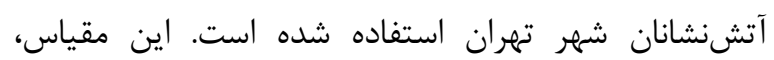

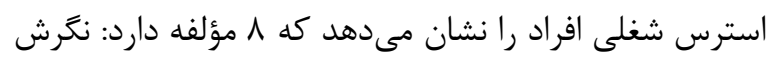

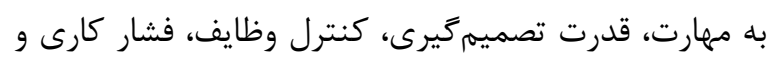

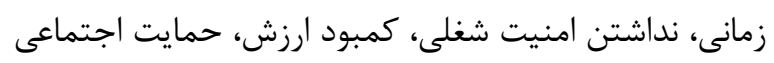

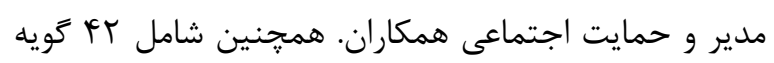

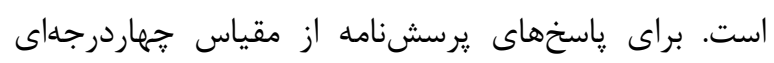

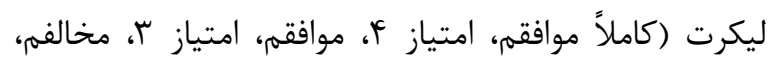

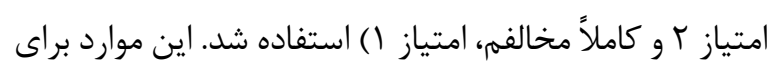

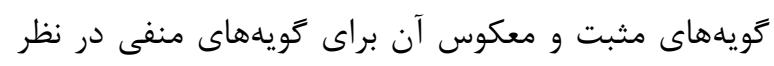

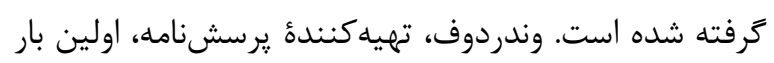

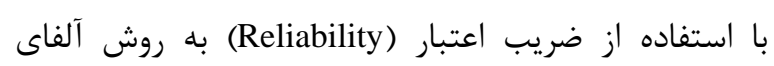

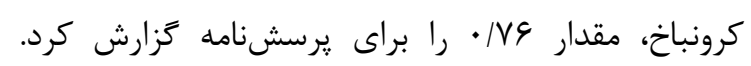

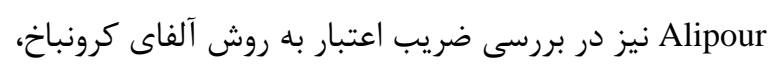

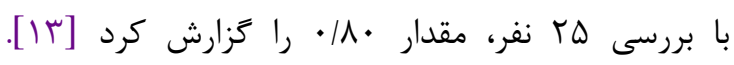
Bakhshi

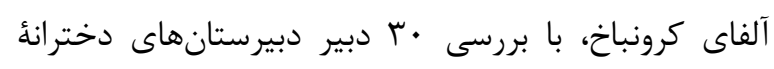

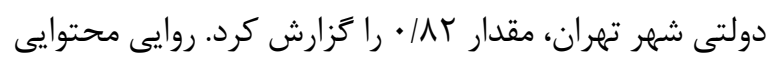

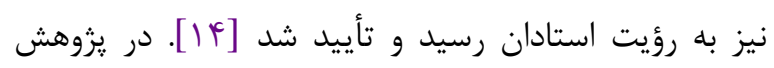

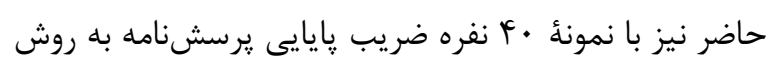

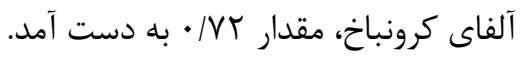

\section{بافته ها}

\section{يافته هاى كيفى}

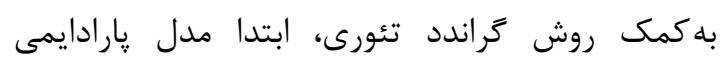

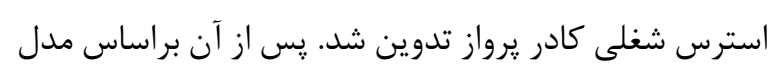

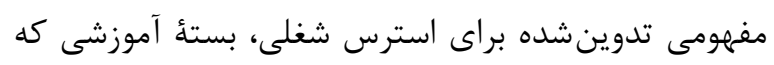

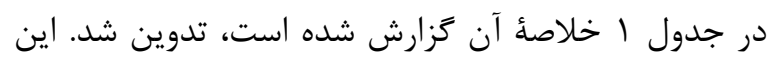

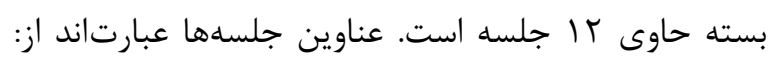

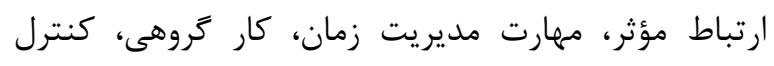

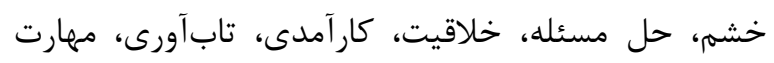
مقابله با استرس، فنون آرميدگى و تعادل كار -خانواده.
يزوهش حاضر به روش تركيبى (Mixed Methods)

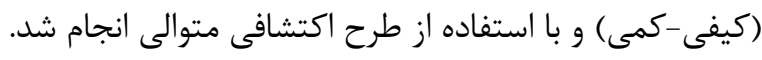

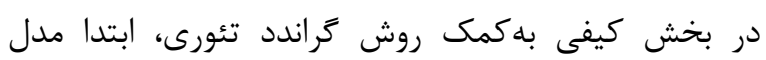

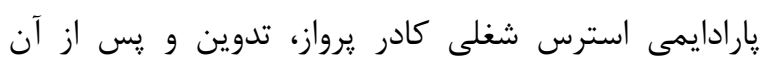

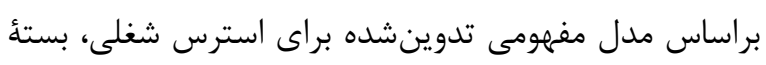

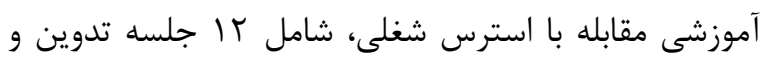

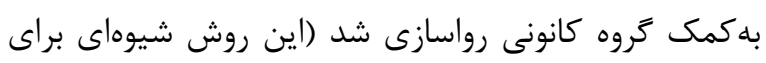

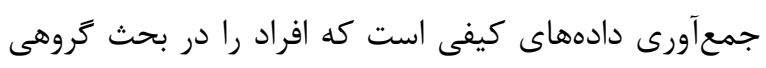

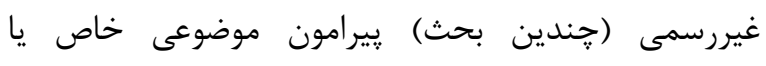

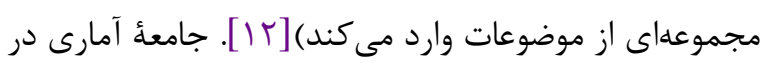
بخش كيفى شامل نخبعان (افرادى كه حداقل دكترى دارى روانشناسى و مشاوره داشتند و در امور مربوط به به مشاورة

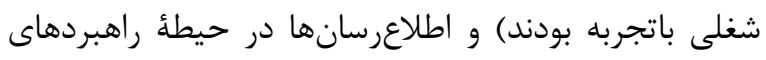

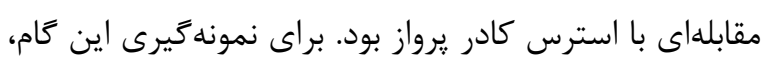

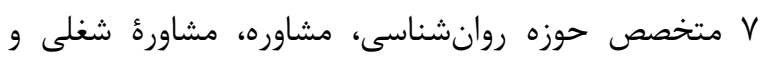

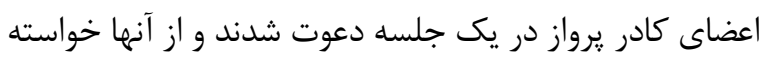

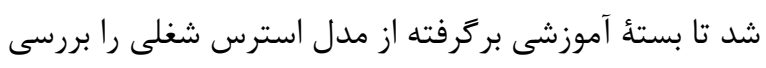

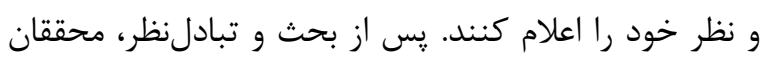
بستهُ آموزشى استخراجى را تأييد كردند.

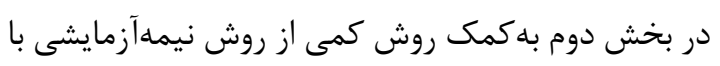
مرح كروه كنترل نامتعادل ( Non- Equivalent Control (Group Design

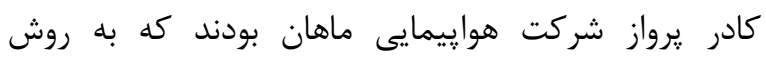

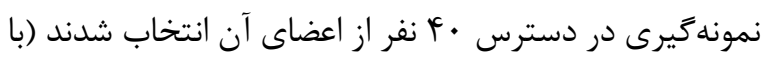

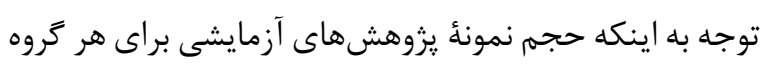

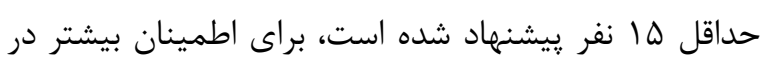

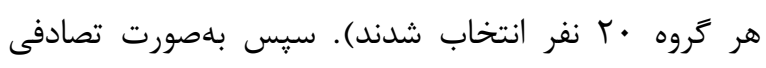

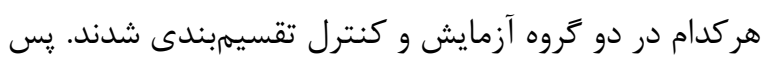

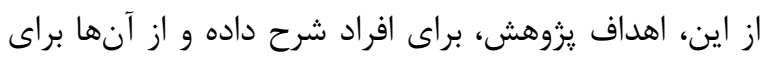

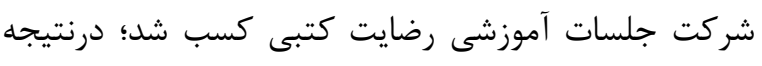

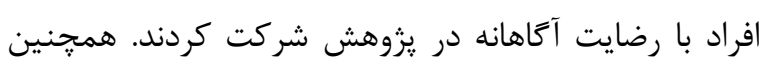

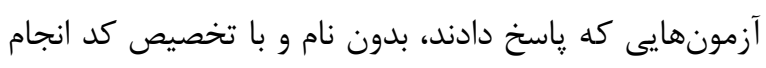

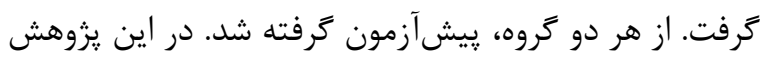

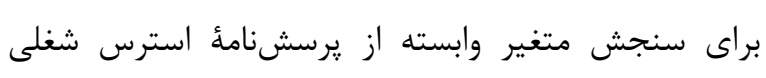

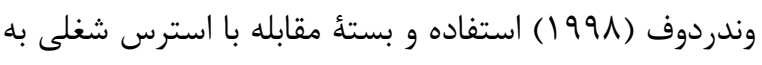

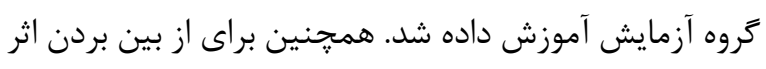

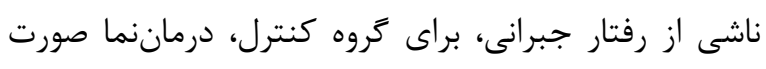

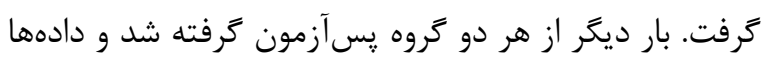

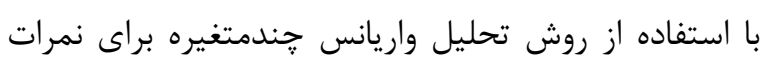


جدول ا. خلاصهاى از جلسههاى بسته آموزشى مقابله با استرس شغلى

\section{طول جلسه}

محتواى جلسئ آموزشى آى جائه اموزتئ معاى

جلسه

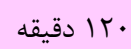

مهارتهاى ارتباط مؤثر با همكاران، خانواده، مسافران

جلسهُ اول

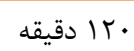

مهارتهاى ارتباط مؤثر با همكاران، خانواده، مسافران

جلسؤ دوم

r r إ دقيقه

آموزش مهارت مديريت زمان

جلسأ سوم

VD

آموزش مهارت كار تروهى

جلسئ جهارم

V دقيقه

آموزش مهارت كنترل خشم

جلسأ پنجمم

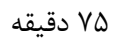

آموزش مهارت حل مسئله

جلسة ششم

VD دقيقه VD

آموزش مهارت خلاقيت

جلسئ هفتمم

VD دقيقه VD

آموزش مهارت خود كار آمدى

جلسة هشتم

• rا دقيقه

آموزش مهارت تابآورى

جلسئ نهم

VD دقيقه VD

آموزش مهارت مقابله با استرس

جلسةٔ دهم

D أ دقيقه

آموزش مهارت فنون آرميدگى

جلسأ يازدهم

S D د V

آموزش مهارت تعادل كار-خانواده

جلسئ دوازدهم

مفروضهُ نرمالبودن نمرات متغير وابسته: براى آزمون

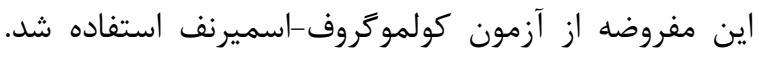

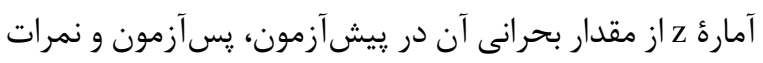

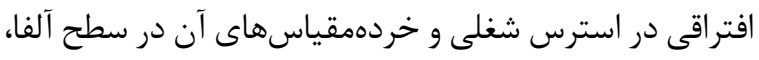

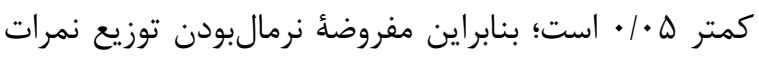

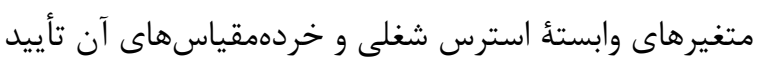

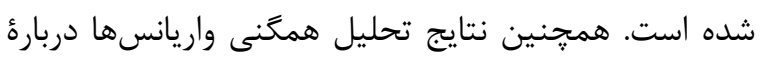

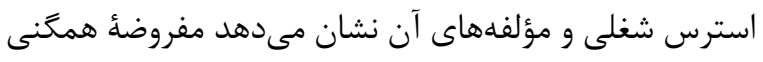

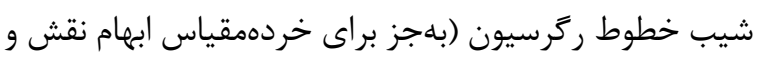
كنترل وظايف) برقرار نيست؛ بنابراين شرايط استفاده از برداي تحليل كوواريانس وجود ندارد.

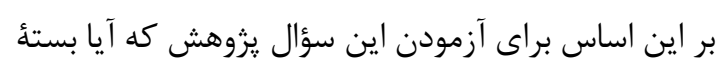

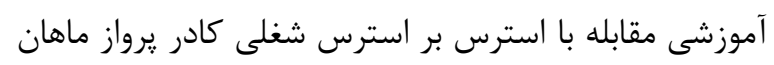

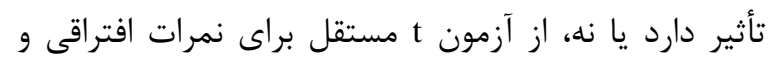

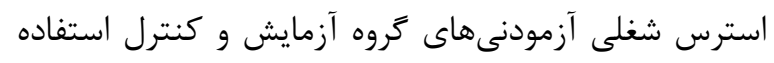

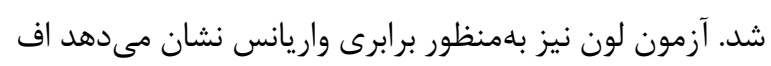

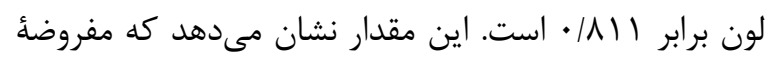

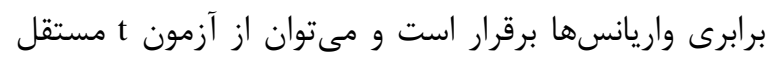

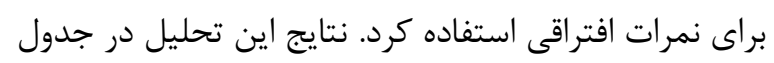

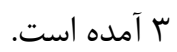

اعتبار درونى بستهٔ آموزشى به كمك مصاحبئ كانونى به دست

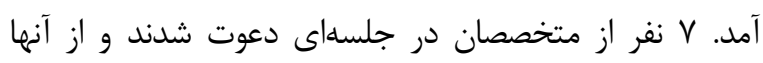

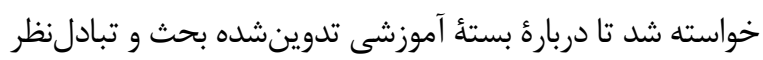

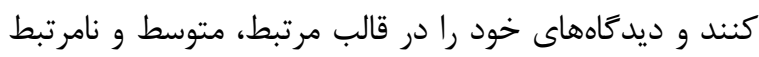

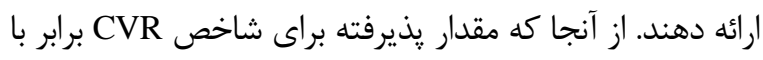

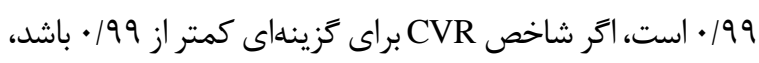

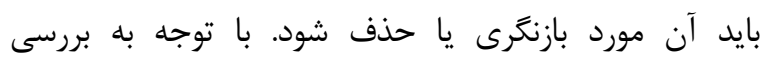

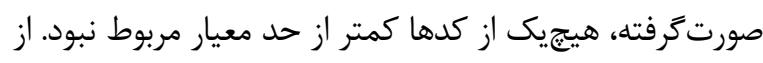

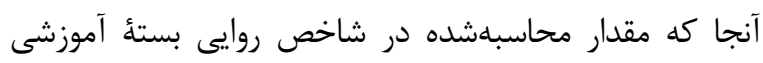

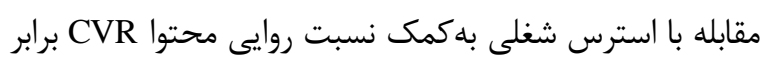

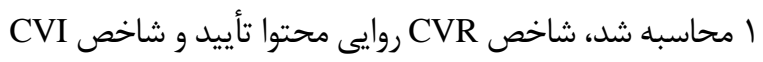

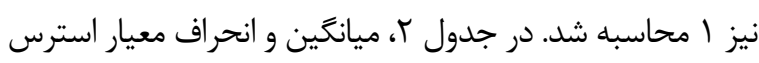

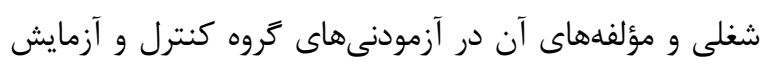

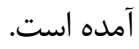

\section{يافتههاى بخش كمى استى}

\section{تحليل استنباطى دادهها: براى تحليل استنباطى از}

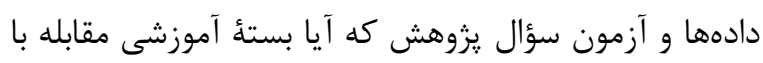

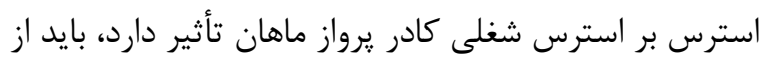

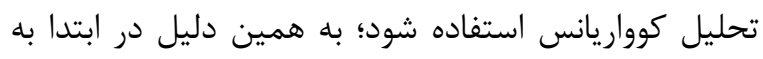
بررسى فرضيههاى تحليل كوواريانس يرداخته شد. 


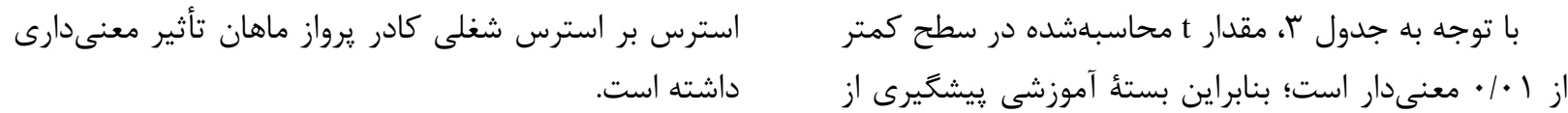

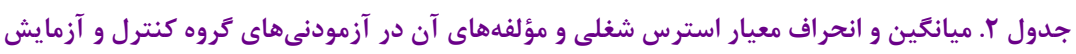

\begin{tabular}{|c|c|c|c|c|c|}
\hline تعداد & انحراف معيار & ميانكَين & تروهها & آزمون & متغير \\
\hline r. & Q/QT & $11 K / \Delta \Delta$ & آزمايش & \multirow{2}{*}{ يِش آزمون } & \multirow{4}{*}{ استرس شغلى } \\
\hline r. & $\varepsilon / \Lambda$. & $119 / 50$ & كنترل & & \\
\hline$r \cdot$ & Ir/ar & $\mid F T / 9 D$ & آزمايش & \multirow{2}{*}{ يسآزمون } & \\
\hline$r \cdot$ & $q / \Gamma V$ & $119 / 1 \Delta$ & كنترل & & \\
\hline r. & ( ו ו & TF/TQ & آزمايش & \multirow{2}{*}{ ِيش آزمون } & \multirow{4}{*}{ نگرش به مههارت } \\
\hline$r \cdot$ & $r / I V$ & $r \Delta / r \Delta$ & كنترل & & \\
\hline r. & N/AV & $r q / 4 \Delta$ & آزمايش & \multirow{2}{*}{ يس آزمون } & \\
\hline$r \cdot$ & I/AV & $r \& / 0$. & كنترل & & \\
\hline r. & $1 / 49$ & $1 \cdot \pi \cdot$ & آزمايش & \multirow{2}{*}{ ِيشآزمون } & \multirow{4}{*}{ تصميم قدرتيرى } \\
\hline$r \cdot$ & $1 / \cdot r$ & $11 / r \Delta$ & كنترل & & \\
\hline r. & $1 / \Gamma 1$ & $\mid r / T$. & آزمايش & \multirow{2}{*}{ يس آزمون } & \\
\hline$r \cdot$ & 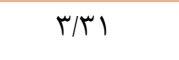 & $1 \cdot 1 \Delta \Delta$ & كنترل & & \\
\hline r. & $1 / 9 T$ & $\mathrm{~V} / \mathrm{l}$ & آزمايش & \multirow{2}{*}{ يِشآزمون } & \multirow{4}{*}{ كنترل وظايف } \\
\hline r. & I/AV & g/ra & كنترل & & \\
\hline r. & $T / T 1$ & $\Lambda / \Lambda$ & آزمايش & \multirow{2}{*}{ يسآزمون } & \\
\hline r. & $T / T V$ & $9 / 9$. & كنترل & & \\
\hline r. & $1 / \pi \Delta$ & $\Delta / 9 \Delta$ & آزمايش & \multirow{2}{*}{ يِيش آزمون } & \multirow{4}{*}{ فشار كارى و } \\
\hline r. & $1 / \cdot \Delta$ & $9 / 90$ & كنترل & & \\
\hline$r \cdot$ & $1 / \Gamma \Delta$ & N/FD & آزمايش & \multirow{2}{*}{ يس آزمون } & \\
\hline r. & $1 / 1 r$ & s/VQ & كنترل & & \\
\hline r. & $1 / V 9$ & $1 F / 0$ & آزمايش & \multirow{2}{*}{ بِيشآزمون } & \multirow{4}{*}{ ابهام نقش } \\
\hline$r \cdot$ & $1 / 49$ & $\mid \Delta / r \Delta$ & كنترل & & \\
\hline r. & $1 / 91$ & $1 N / F \Delta$ & آزمايش & \multirow{2}{*}{ يسآزمون } & \\
\hline$r \cdot$ & $1 / 94$ & $\mid Q / 1$ & كنترل & & \\
\hline r. & $1 / 1 V$ & $9 / \vee \cdot$ & آزمايش & \multirow{2}{*}{ يِيشآزمون } & \multirow{4}{*}{ نداشتن امنيت } \\
\hline$r \cdot$ & $1 / \Delta F$ & $9 / \Lambda$. & كنترل & & \\
\hline$r \cdot$ & T/T & $I T / V$ & آزمايش & \multirow{2}{*}{ پِ آزمون } & \\
\hline$r \cdot$ & (KG & $9 / \wedge \Delta$ & كنترل & & \\
\hline$r \cdot$ & $\cdot \mid \mathrm{A} \Lambda$ & $1 \cdot 19$ & آزمايش & \multirow{2}{*}{ يِيشآزمون } & \multirow{4}{*}{ كمبود ارزش } \\
\hline$r \cdot$ & $1 / 1 F$ & $11 / 4 \Delta$ & كنترل & & \\
\hline r. & $1 / 49$ & $11 / 0$ & آزمايش & \multirow{2}{*}{ يس آزمون } & \\
\hline r. & I/AT & $1 \cdot 10$ & كنترل & & \\
\hline$r \cdot$ & $1 / 94$ & $\mid F / T$. & آزمايش & \multirow{2}{*}{ يِيش آزمون } & \multirow{4}{*}{ حمايت اجتماعى } \\
\hline$r \cdot$ & $1 / 1$ & $\mid f / \Delta \Delta$ & كنترل & & \\
\hline$r \cdot$ & $1 / 19$ & $11 / 90$ & آزمايش & \multirow{2}{*}{ يسآزمون } & \\
\hline$r \cdot$ & $1 / 99$ & $14 / 9$. & كنترل & & \\
\hline
\end{tabular}


شيوا سخائى و همكاران | تدوين و مطالعهٔ اثربخشى بستهٔ آموزشى مقابله با استرس شغلى كادر يرواز

\begin{tabular}{|c|c|c|c|c|c|}
\hline تعداد & انحراف معيار & ميانتين & تروهها & آزمون & متغير \\
\hline$r$. & $1 / 99$ & $19 / 10$ & آزمايش & \multirow{2}{*}{ קֵيشآزمون } & \multirow{4}{*}{ حمايت اجتماعى } \\
\hline$r$. & $1 / \Delta r$ & $\mid \omega / F$ & كنترل & & \\
\hline$r$. & $1 / V \wedge$ & Tr/AD & آزمايش & \multirow{2}{*}{ ڤس آزمون } & \\
\hline$r$. & $r / \Delta \cdot$ & $10 / \Lambda$ & كنترل & & \\
\hline
\end{tabular}

\begin{tabular}{|c|c|c|c|c|c|c|}
\hline$P$ & d.f & $\mathbf{T}$ & $\mathbf{S}$ & $\mathbf{M}$ & تعداد & كرومها \\
\hline$\cdot|\cdots \cdot|$ & rı & $-\Lambda / Y \Lambda I$ & $1 r / 9 F$ & $-r \mid / l$. & $r$. & كنترل \\
\hline & & & 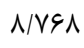 & $-\cdot 19$. & $r$. & آزمايش \\
\hline
\end{tabular}

متغيرهاى وابسته (مؤلفههاى استرس شغلى) لازم است بلتنهايى در آزمودنىهاى گروههاى آزمايش و كنترل از تحليل واريانس يكىراهه براى نمرات افتراقى استفاده شود. از آنجا كه

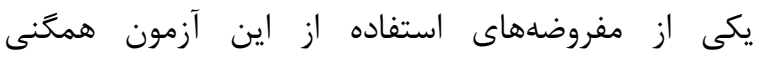

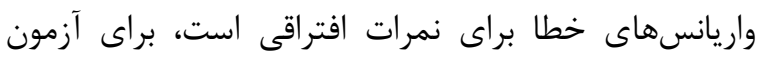
همخَى واريانس هاى خطا از آزمون لون استفاده شد كه نتايج

$$
\text { آن در جدول ه آمده است. }
$$

جدول ه نشان مى ندهد همگنى واريانسهاى خطا، بهجز براى

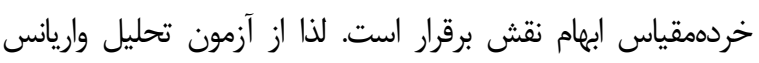
يكراهل، براى نمرات افتراقى در دو گروه آزمايش و كنترل، استفاده شد. بردي.
در جدول ₹ نيز خلاصةٔ نتايج تحليل واريانس جندمتغيره براى نمرات افتراقى استفادهده در اين مورد ززارش شده است. نتايج جدول f نشان مىدهد ميان سطوح آموزش بسته

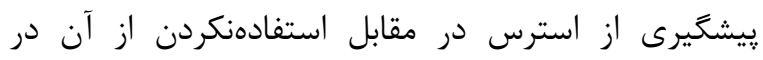
مؤلفههاى استرس شغلى، حداقل در يكى از اين مؤلفهها تفاوت معنى دارى وجود دارد. [9 | | | • =

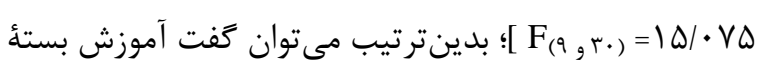
ييشگيرى از استرس حداقل بر يكى از مؤلفههاى استرس

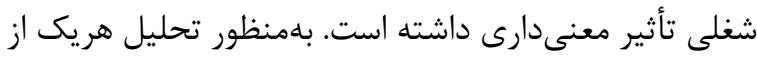

جدول f. خلاصة تحليل واريانس خندمتغيره براى نمرات افتراقى مؤلفههاى استرس شغلى

\begin{tabular}{|c|c|c|c|c|c|c|c|}
\hline توان آمارى & & $P$ & F & D.f2 & D.f1 & مقادير & آزمونها \\
\hline 1 & .1119 & $P<\cdot 1 \cdots 1$ & $|\Delta| \cdot V \Delta$ & $r$. & 9 & $\cdot 1119$ & اثر پيلايى \\
\hline 1 & .1119 & $P<\cdot / \cdots 1$ & $\mid \Delta / \cdot V \Delta$ & $r$. & 9 & $\cdot|11|$ & لامبداويلكز \\
\hline 1 & .1119 & $P<\cdot \mid \cdots 1$ & $|Q| \cdot V \Delta$ & r. & 9 & F/OTR & هتلينَ \\
\hline 1 & .1119 & $P<\cdot \mid \cdots 1$ & $\mid \Delta / \cdot V \Delta$ & $\mu$. & 9 & F/OTK & ريشه روى \\
\hline
\end{tabular}

جدول ه. نتايج آزمون لون براى همَنى واريانسهاى خطاى نمرات افتراقى مؤلفههاى استرس شغلى

\begin{tabular}{|c|c|c|c|c|}
\hline$P$ & d.f2 & d.f1 & نسبت & متغير \\
\hline$\cdot 11 \cdot 9$ & rᄉ & 1 & $r / 99 \Delta$ & نخرش به ممهارت \\
\hline$\cdot / 1 \mathrm{~F}$. & ऍᄉ & 1 & T/TVG & قدرت تصميمثيرى \\
\hline$\cdot / 9 \cdot 1$ & rᄉ & 1 & $\cdot / \cdot \Delta \Delta$ & كنترل وظايف \\
\hline 1 & ऍ & 1 & $\cdots$ & فشار كارى \\
\hline ./.re & rی & 1 & $F / V \cdot r$ & ابهام نقش \\
\hline.$/ 1 \mathrm{FF}$ & rᄉ & 1 & $T / T r \mid$ & نداشتن امنيت شغلى \\
\hline$\cdot|\Delta \Delta|$ & rᄉ & 1 & 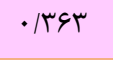 & كمبود ارزش \\
\hline - $/ \Delta T V$ & rی & 1 & $\cdot / \cdot \Lambda \mu$ & حمايت اجتماعى مدير \\
\hline
\end{tabular}




حمايت اجتماعى همكاران

در جدول 4 نيز خلاصُٔ تحليل آزمون آمارى تحليل استرس شغلى با استفاده از آلفاى تعديلشده بنفرونى

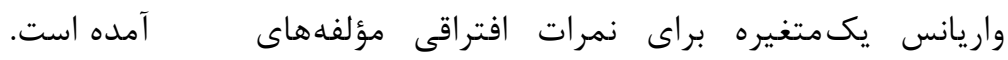

جدول 9. خلاصُٔ تحليل واريانس يك متغيره براى ذمرات افتراقى مؤلفههاى استرس شغلى

\begin{tabular}{|c|c|c|c|c|c|c|c|}
\hline توان آمارى & $\eta^{r}$ & $P$ & F & M.S & d.f & S. $\mathbf{S}$ & متغير وابسته \\
\hline \multirow{2}{*}{$\cdot / f V F$} & \multirow{2}{*}{$.1 \cdot 9}$. & \multirow{2}{*}{$\cdot 1 \cdot \Delta 9$} & \multirow{2}{*}{ r/VVG } & IFA/TYA & 1 & IFA/TYL & نكرش به مهارت \\
\hline & & & & $r q / r \Delta l$ & rᄉ & $|f q| / \Delta \Delta$ & خطا \\
\hline \multirow{2}{*}{. $/ A T}$. & \multirow{2}{*}{.1119} & \multirow{2}{*}{$\cdot 1 \cdot \Delta$} & \multirow{2}{*}{$\Lambda / V \cdot \varphi$} & $V T / 9 \ldots$ & 1 & $V Y / q \ldots$ & قدرت تصميمگيرى \\
\hline & & & & $\Lambda / r V F$ & rᄉ & $r \mid \Lambda / r .$. & خطا \\
\hline \multirow{2}{*}{$\cdot|\mu F|$} & \multirow{2}{*}{$.1 \cdot 94$} & \multirow{2}{*}{.$/ 1 T}$. & \multirow{2}{*}{ T/QYT } & $\mid r / r T \Delta$ & 1 & $\mid r / r T \Delta$ & كنترل وظايف \\
\hline & & & & $\Delta / Y F \mid$ & ץ^ & $199 / 10$. & خطا \\
\hline \multirow{2}{*}{1} & \multirow{2}{*}{$\cdot / 4 \vee q$} & \multirow{2}{*}{$\cdot 1 \cdot \cdots 1$} & \multirow{2}{*}{ rF/qqu } & $1 \cdot r / F \cdot$. & 1 & $1 \cdot T / F \cdot$. & فشار كارى و زمانى \\
\hline & & & & T/9TG & rی & $111 / r \ldots$ & خطا \\
\hline \multirow{2}{*}{1} & \multirow{2}{*}{$\cdot / F \wedge F$} & \multirow{2}{*}{$\cdot 1 \cdot \cdots 1$} & \multirow{2}{*}{$r \Delta / \Delta \wedge \vee$} & $19 \wedge / 1 \ldots$ & 1 & $19 \wedge / 1 \ldots$ & ابهام نقش \\
\hline & & & & F/VYF & rᄉ & IVq/D... & خطا \\
\hline \multirow{2}{*}{$\cdot / T \Delta \Delta$} & \multirow{2}{*}{$\cdot 1 \cdot i \Delta$} & \multirow{2}{*}{.119} & \multirow{2}{*}{$1 / V \vee q$} & $\Lambda V / \cdot r \Delta$ & 1 & $\Lambda V / \cdot r \Delta$ & نداشتن امنيت شغلى \\
\hline & & & & FN/9T & rᄉ & $1 \wedge \Delta N / 9 \Delta$ & خطا \\
\hline \multirow{2}{*}{. /9६5 } & \multirow{2}{*}{. ITVD } & \multirow{2}{*}{$\cdot|\cdots|$} & \multirow{2}{*}{$\mid F / \varepsilon \Delta F$} & TF/TTQ & 1 & TYKTHD & كمبود ارزش \\
\hline & & & & GTr/T & r^ & $\Lambda \Lambda / V \Delta$ & خطا \\
\hline \multirow{2}{*}{1} & \multirow{2}{*}{$\cdot 10 \cdot V$} & \multirow{2}{*}{$\cdot|\cdots|$} & \multirow{2}{*}{$r q / \cdot v$. } & $194 / 9$. & 1 & $194 / 9$ & حمايت اجتماعى مدير \\
\hline & & & & $F / 9 \Delta \Delta$ & ץᄉ & $\mid \Lambda \Lambda / r$. & خطا \\
\hline \multirow{2}{*}{1} & \multirow{2}{*}{.19.} & \multirow{2}{*}{$\cdot \mid \cdots 1$} & \multirow{2}{*}{$\Delta q / 9 / F$} & एवя/q. & 1 & тqя/q. & حمايت اجتماعى همكاران \\
\hline & & & & q/9Vt & rᄉ & $r \& \Delta / .$. & خطا \\
\hline
\end{tabular}

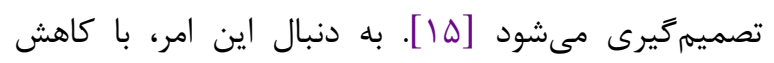

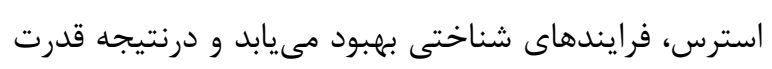

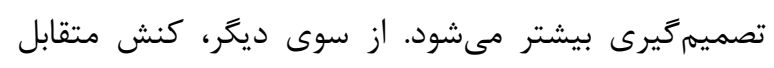

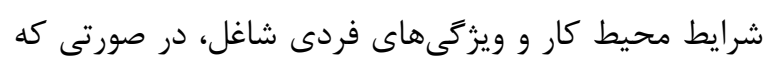

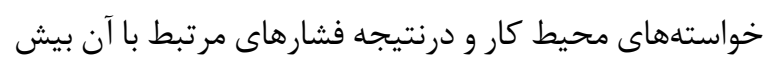

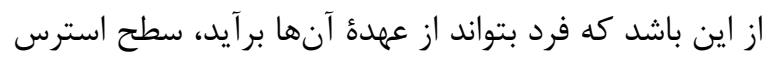

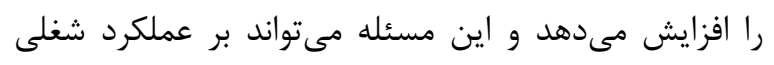

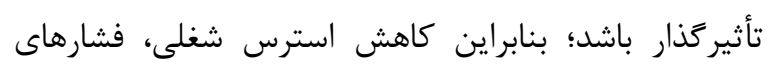

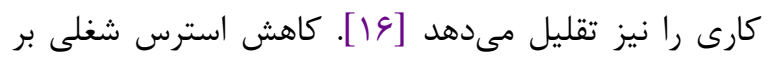

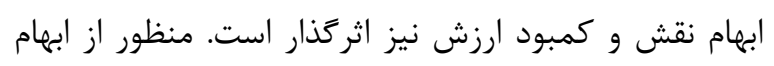

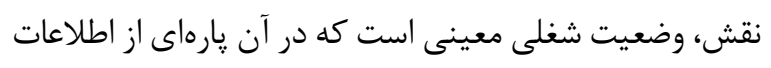

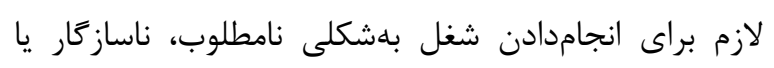

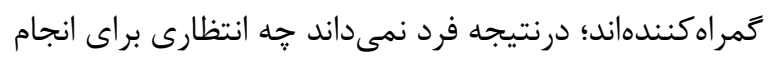

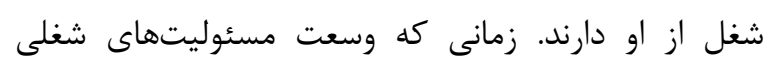

\section{بحث}

يزوهش حاضر با هدف تدوين بستؤ آموزشى مقابله با بادي استرس شغلى و تعيين اثربخشى آن در كاركنان كادر يرواز

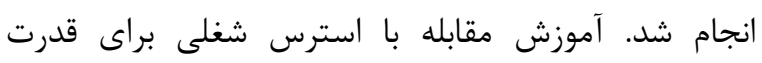

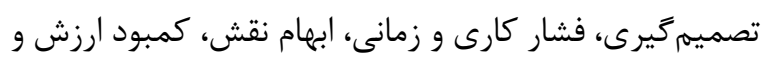

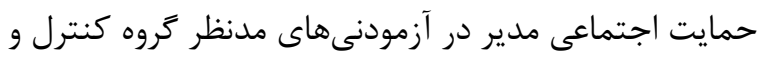

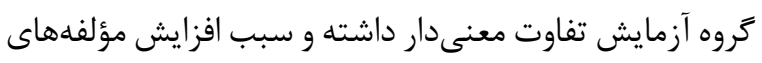

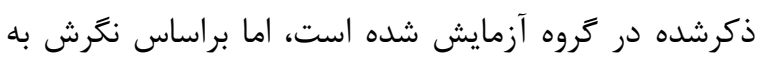
مهارت، كنترل وظايف و نداشتن امنيت شغلى، درو آموزش مقابله

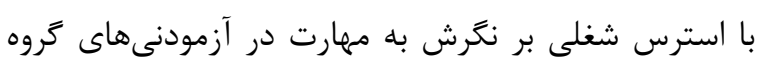

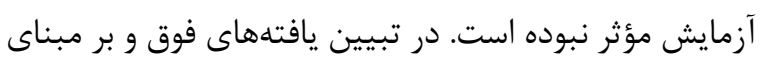

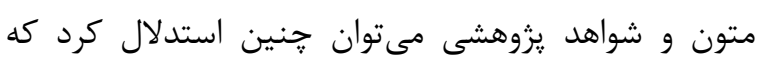
سطوح بالاى استرس مىتواند سبب اختلال در فرايند تفكر،

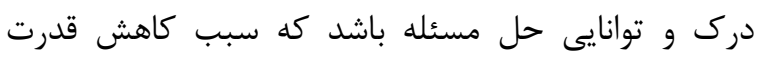


نتيجه

براساس نتايج، بستهٔ آموزشى مقابله با استرس، تأثير

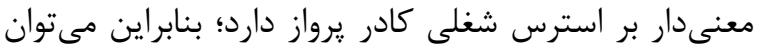

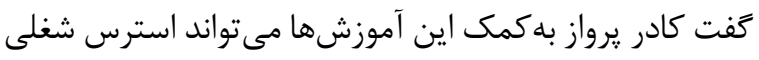

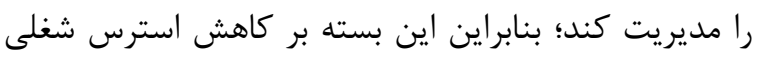

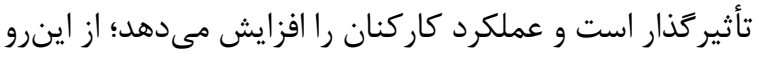

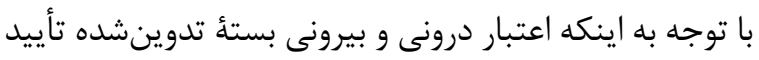

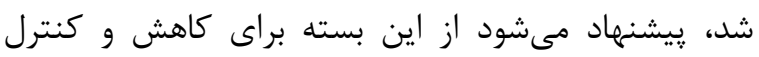

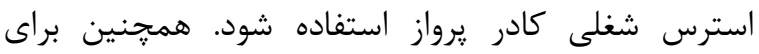
مشاوران و درمانكرانى كه قصد درمان استرس شغلى كادر

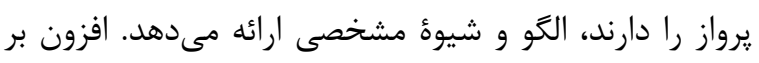

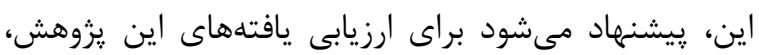

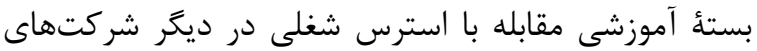

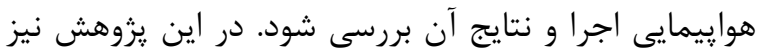

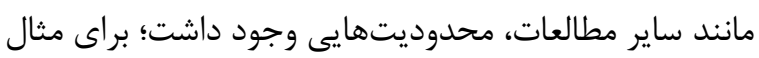
با توجه به اينكه اين يزوهش در شركت هواييمايى ماهان

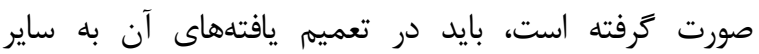
شركتهاى هواييمايى و مشاغل ديخر جانب احتياط را رعايت كرد.

\section{تقدير و تشكر}

اين يزوهش در قالب پاياننامٔ دكترى در دانشكده

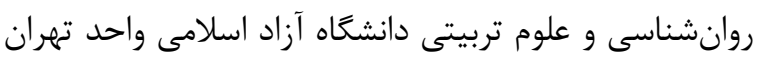

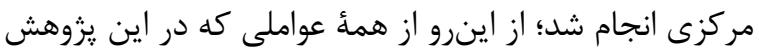

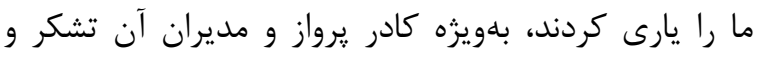
قدردانى مى كنيم. - مارى كردنا،

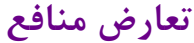

بين نويسندًان هيجَّونه تعارضى در منافع وجود ندارد.

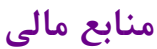

منابع مالى اين مطالعه توسط نويسندكان تامين شده است.

\section{References}

1. Hon AH. Does job creativity requirement improve service performance? A multilevel analysis of work stress and service environment. International Journal of Hospitality Management. 2013 Dec 1;35:161-70. [DOI:10.1016/j.ijhm.2013.06.003]
ساختارمند نباشد، يا ضعيف تعريف شده باشد، ابهام نقش به به به به وجود مى آيد [IV] . يشتيبانى و حمايت مدير و اعضاى گروه

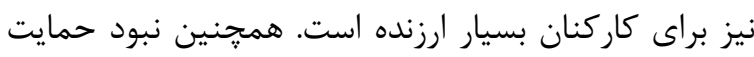

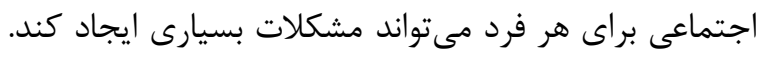
براساس يزوهشها افزايش حمايت اجتماعى بهعنوان ويزگى ها

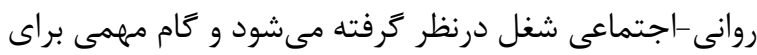

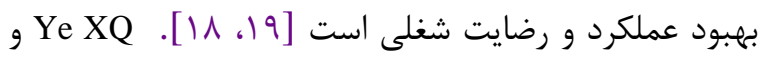

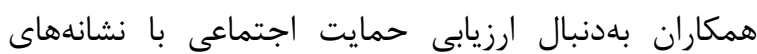

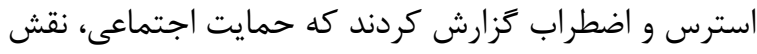
عوامل استرسزا را كاهش مىدهد و و عامل حفاظتى در برابر

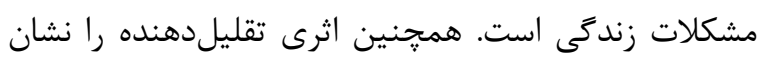
مى دهد كه وقتى افراد با استرس زيادى مواجه هستند، از آنها

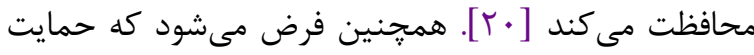

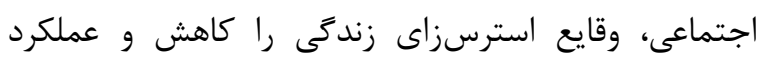

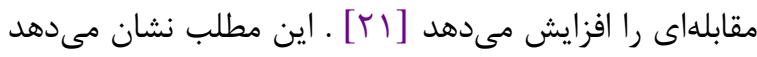

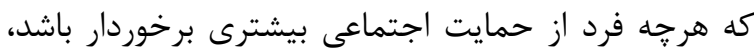
آسيب پذيرىاش در برابر استرس كمتر مىشود. اين نتيجه با

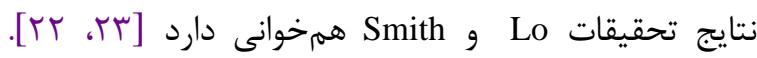
يروهشگران برجسته درباره عملكرد مقابلهاى توافق دارند كه

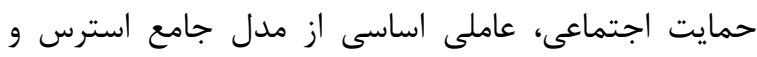

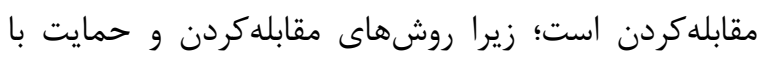
يكديخر تركيب مىشوند [TF]. بستة آموزشى ييشخيرى از استرس تأثير معنى مدارى برن استرس شغلى كادر يرواز ماهان دارد. اين يافته با نتايج

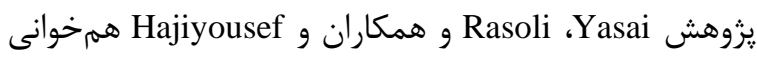
دارد [عr، ه r، 9]. در اين مطالعات، به ضرورت اجراى برنامهاى جامع درمورد مديريت استرس كاركنان اشاره شده

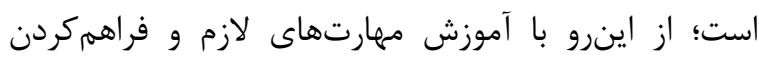
امكانات شغلى مىتوان ميزان بهرهورى افراد را افزايش داد. در

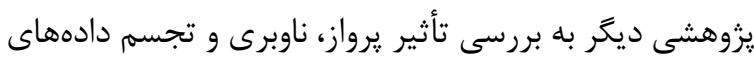

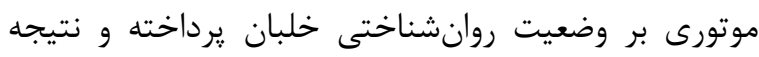
گرفته شد گروهى كه آموزش كستردهتر و جامعترى درباره كابين خلبان داشتند، سطح استرس كمترى را نشان دادند

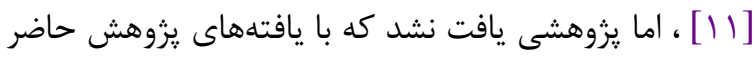
همسو باشد.

2. Mesler R, Capobianco M. Psychosocial factors associated with job stress. Stress news. 2001;13(4):22-4. 
3. Ford MT. Job-occupation misfit as an occupational stressor. Journal of Vocational Behavior. 2012 Apr 1;80(2):412-21. [DOI:10.1016/j.jvb.2011.10.004]

4. Hu HY, King B. Impacts of misbehaving air passengers on frontline employees: role stress and emotional labor. International Journal of Contemporary Hospitality Management. $2017 \mathrm{Jul}$ 10.29(7): 1793-1831. [DOI:10.1108/IJCHM-092015-0457]

5. Rohollahi AA, Ahadmotlaghi E. Job stress among air traffic controllers. EBNESINA. 2014 May 10;16(1):79-80.

6. 6 Theorell T. Commentary triggered by the Individual Participant Data Meta-Analysis Consortium study of job strain and myocardial infarction risk. Scandinavian journal of work, environment $\&$ health. 2014 Jan 1:89-95. [DOI:10.5271/sjweh.3406] [PMID]

7. VOSOUGHI NA, ROHOLLAHI A, MOHAMAD $\mathrm{HH}$. The effect of job stress on general health and job performance on air traffic controllers (atc).Iran Occupational Health.2016;13(1):47-57.

8. Omholt ML, Tveito TH, Ihlebæk C. Subjective health complaints, work-related stress and self-efficacy in Norwegian aircrew. Occupational Medicine. 2017 Mar 1;67(2):135-42. [DOI:10.1093/occmed/kqw127] [PMID]

9. Ahmadi K, Alireza K. Stress and job satisfaction among air force military pilots.2007;1;3(3):159-63. [DOI:10.3844/jssp.2007.159.163]

10. Maymand MM, Shakhsian F, Hosseiny FS. The effect of stress on flight performance. World Applied Sciences Journal. 2012;19(10):1381-7.

11. Socha V, Schlenker J, Kal'avksý P, Kutilek P, Socha L, Szabo S, Smrčka P. Effect of the change of flight, navigation and motor data visualization on psychophysiological state of pilots. In2015 IEEE 13th International Symposium on Applied Machine Intelligence and Informatics (SAMI) 2015 Jan 22 (pp. 339-344).

IEEE.

[DOI:10.1109/SAMI.2015.7061900]

12. Wilkinson S, Silverman D. 10 Focus Group Research. Qualitative research: Theory, method and practice. 2004; 25:177-99.

13. Alipour R. The study of job stress and effective factors on it, in firefighters of Tehran fire safety services organization (Doctoral dissertation, Thesis work in Medicine, Tehran University of Medical Sciences.(Persian)).

14. Ziapour A, Khatony A, Jafari F, Kianipour N. Evaluation of time management behaviors and its related factors in the senior nurse managers, Kermanshah-Iran. Glob J Health Sci. 2015;7(2):36673. [DOI:10.5539/gjhs.v7n2p366] [PMID] [PMCID]

15. Niknami M, Dehghani F, Bouraki S, Kazem Nejad Leili E, Soleimani R. Strategies among Students of Guilan University of Medical Sciences. Journal of Holistic Nursing and Midwifery. 2014;10(4):62-8.
16. Ras R, Altaymer E. job stress, translated by G. Khajehpour. Industrial Management Institute Publications. 2002.

17. Basami A, CHizari M,Abbasi E.Relationship Between Job Characteristics and Job Burnout among Jihad-e Keshavarzi Organization Specialists in Kurdistan province. Agricultural Extension and Education Research.2015;7(4):27-42.

18. MacDonald LA, Deddens JA, Grajewski BA, Whelan EA, Hurrell JJ. Job stress among female flight attendants. Journal of occupational and environmental medicine. 2003 Jul 1;45(7):703-14. [DOI:10.1097/01.jom.0000071509.96740.dd] [PMID]

19. Irving AV. Occupational Stress and Law Enforcement Officer Significant Relationships (Doctoral dissertation, Northcentral University).

20. Ye XQ, Chen WQ, Lin JX, Wang RP, Zhang ZH, Yang X, Yu XQ. Effect of social support on psychological-stress-induced anxiety and depressive symptoms in patients receiving peritoneal dialysis. Journal of psychosomatic research. 2008 Aug $1 ; 65(2): 157-64$ [DOI:10.1016/i.jpsychores.2008.04.007] [PMID]

21. Årestedt K, Saveman BI, Johansson P, Blomqvist K. Social support and its association with health-related quality of life among older patients with chronic heart failure. European Journal of Cardiovascular Nursing. 2013 Feb;12(1):69-77. [DOI:10.1177/1474515111432997] [PMID]

22. Lo R. A longitudinal study of perceived level of stress, coping and self-esteem of undergraduate nursing students: an Australian case study. Journal of advanced nursing. 2002 Jul;39(2):119-26. [DOI:10.1046/j.1365-2648.2000.02251.x] [PMID]

23. Smith CS. Coping strategies of female victims of child abuse in treatment for substance abuse relapse: their advice to other women and healthcare professionals. Journal of Addictions Nursing. 2007 Jan

$1 ; 18(2): 75-80$. [DOI:10.1080/10884600701334929]

24. Chalk HM. Coping with multiple sclerosis: Coping strategies, personality, and cognitive appraisals as predictors of adjustment among multiple sclerosis patients (Doctoral dissertation, The Ohio State University).

25. Rasoli Z. Survey relationship job stress and burnout with rat productivity in helicopter pilots.. 2012; 10(2):133-137.

26. Hajiyousefi H, Asadi H, Jafari A. Work Stress among Flight Attendants; The Perspective of a Standard Sports Examination Designing as a Prerequisite to Flight License. International Research Journal of Applied and Basic Sciences. 2017;11(1):31-40. 